This item is the archived peer-reviewed author-version of:

Environmental and health impacts of effluents from textile industries in Ethiopia : the case of Gelan and Dukem, Oromia Regional State

\title{
Reference:
}

Dadi Diriba, Stellmacher Till, Senbeta Feyera, Van Passel Steven, Azadi Hossein.- Environmental and health impacts of effluents from textile industries in Ethiopia : the case of Gelan and Dukem, Oromia Regional State

Environmental monitoring and assessment - ISSN 0167-6369 - 189:1(2017), 11

Full text (Publisher's DOI): http://dx.doi.org/doi:10.1007/S10661-016-5694-4

To cite this reference: http://hdl.handle.net/10067/1390390151162165141 


\section{Environmental and Health Impacts of Effluents from Textile Industries in Ethiopia: The Case of Gelan and Dukem, Oromia Regional State}

Diriba Dadi ${ }^{\mathrm{a}}$, Till Stellmacher ${ }^{\mathrm{b}}$, Feyera Senbeta ${ }^{\mathrm{c}}$, Steven Van Passel ${ }^{\mathrm{d}}$, Hossein Azadi ${ }^{\text {d,e,f,* }}$
${ }^{a}$ College of Social Science and Humanities, Department of Geography, Madda Walabu University, Ethiopia

${ }^{b}$ Center for Development Research (ZEF), University of Bonn, Germany

${ }^{c}$ College of Development Studies (CDS), Addis Ababa University, Ethiopia

${ }^{d}$ Department of Environmental Economics, Hasselt University, Belgium

${ }^{e}$ Economics and Rural Development, University of Liège, Belgium.

${ }^{f}$ Department of Geography, Ghent University, Belgium

* Corresponding author. Email: hossein.azadi@ugent.be, Tel. +32 (0)9 26446 95. Fax +32 (0)9 26449 85 .

\section{Acknowledgment}

In preparing this work, different organizations and institutions contributed immensely and therefore deserve acknowledgment. I would like to thank WHO for their financial support in collecting field samples, the purchase of chemicals, and various types of equipment required for the laboratory activities. I would also like to thank DAAD and the Post Graduate Program at Addis Ababa University for their financial support during my field stay in order to conduct the household survey. The authors wish to thank Ms. Bethany Gardner from the Department of Linguistics, the State University of New York at Binghamton, for her kind help in improving the English of this text. 


\section{Environmental and Health Impacts of Effluents from Textile Industries in}

2 Ethiopia: The Case of Gelan and Dukem, Oromia Regional State

\section{Abstract}

5 This study focuses on four textile industries (DH-GEDA, NOYA, ALMAHDI and ALSAR) established

6 between 2005 and 2008 in the peri-urban areas of Dukem and Gelan. The objectives of the study were

7 to generate baseline information regarding the concentration levels of selected pollutants and to analyze

8 their effects on biophysical environments. This study also attempts to explore the level of exposure

9 humans and livestock have to polluted effluents and the effects thereof. The findings of this study are

10 based on data empirically collected from two sources: laboratory analysis of sample effluents from the

11 four selected textile plants and quantitative as well as qualitative socio-economic data collection. As

12 part of the latter, a household survey and Focus Group Discussions (FGDs) with elderly and other focal

13 persons were employed in the towns of Dukem and Gelan. The results of the study show that large

14 concentrations of $\mathrm{BOD}_{5}, \mathrm{COD}$, TSS and $\mathrm{pH}$ were found in in all the observed textile industries, at

15 levels beyond the permissible discharge limit set by the national EPA. Furthermore, $\mathrm{S}_{2}, \mathrm{R}_{-} \mathrm{PO}_{4}{ }^{3}$ and $\mathrm{Zn}$

16 were found in large concentrations in DH-GEDA and ALMHADI, while high concentrations was also

17 identified in samples taken from ALSAR and ALMHADI. In spite of the clear-cut legal tools, this

18 study shows that the local environment, people, and their livestock are exposed to highly contaminated

19 effluents. We therefore recommend that the respective federal and regional government bodies should

20 re-examine the compliance to and actual implementation of the existing legal procedures and

21 regulations, and respond appropriately.

22 Keywords: Pollution assessment; Environmental quality; Human health; Water pollution; Textile effluent. 


\section{Introduction}

26 Industries are often considered as an 'engine' of economic growth (Azadi et al. 2011; Siyanbola et al. 2011) by which many countries promote their rapid economic growth. The textile industry is one of the most important sub-sectors of the manufacturing industry that contributes or contributed to the transformation of economies in countries such as China, Bangladesh, India, Vietnam, Turkey, and Nigeria (Islam et al. 2011; UNIDO 2012; Tran 2013; Singh et al. 2013). In Bangladesh, e.g., the textile and garment sector contributes to about $77 \%$ of the country's foreign earnings and employs $50 \%$ of the industrial work force (Islam et al. 2011).

Albeit, studies have shown that textile industries also have strong negative environmental impacts, often associated with water pollution (Sponza 2002; Islam et al. 2011; Siyanbola et al. 2011; Khan and Malik 2014; www.oecotextile.com (21/7/2014)). In most textile industries operating in developing or transition countries, wastewater treatment is nonexistent, nonfunctional, or inefficient, leading to massive environmental pollution and health problems (Pamo 2004; Islam et al. 2011; Siyanbola et al. 2011; Paul et al. 2012).

Textile industries consume large volumes of water and chemicals at different stages of the wet processing phases. According to Khan and Malik (2014), one textile plant can use as many as 2000 different chemicals, from dyes to transfer agents. It can also use close to 2270 liters of water in order to complete the production of less than 10 meters of fabrics (Islam et al. 2011). Huge amounts of water are needed for bleaching, dyeing, and for conveying chemicals used in the dying process, as well as for cleaning the machines after each textile production phase. According to Govindarajalu (2003), the water consumption of an average-sized textile mill (with a production of around 8,000 $\mathrm{kg}$ of fabric per day) is about 1.6 million liters per day. This kind of textile plant can also generate up to $200-350 \mathrm{~m}^{3}$ of effluents per ton of finished products (Ranganathan et al. 2007; Gozálvez-Zafrilla et al. 2008), resulting in an average pollution of $100 \mathrm{~kg}$ chemical oxygen demand (COD) per ton of fabric (Jekel 1997). The same studies have also revealed the presence of high amounts of pollutants in textile industry wastewater. For instance, the effluents from the dye bath had contained COD of 5000-6000 mg/l, $52,000 \mathrm{mg} / 1$ of total dissolved solids (TDS), 2,000 mg/l of Suspended Solids (SS), and pH 9 (Verma et al. 2012; Khan and Malik A2014).

53 Many studies have also revealed the negative impacts of such pollution. Mark (2004), Kumer et al. 54 (2012), and Manunatha (2008), for example, have shown that industrial effluents polluting the soil can 55 affect plant growth, including agricultural crops and, apparently, affect the livelihood of farmers in the area. On the other hand, Kovaipunder (2003) studied the effects of water pollution on the health status 
of the people using polluted water, using the Noyyal River as a case study in three districts in Southern

58 India. In this context, Kovaipunder proved that health problems such as skin allergy, respiratory

59 infections, general allergies, gastritis, and ulcers are prevalent in all of the 31 sampled villages.

60 Khan and Malik (2014) also conducted a study on the environmental and health effects of textile

61 effluents in India. They showed that untreated or insufficiently treated textile effluents contain

62 chemicals that can pollute the air people breath, causing respiratory health problems. In this study,

63 Khan and Malik also discovered that effluents with high concentrations of chemical pollutants affect

64 normal functions of human cells, especially in the case of fetuses, infants, and children. According to

65 the findings of Khan and Malik, some textile pollutants in higher concentrations can alter the 66 physiology and biochemical mechanisms of humans, resulting in the impairment of the physiological

67 functions such as Osmoregulation, reproduction, and can sometimes cause death. For instance, heavy

68 metals present in textile effluents can easily accumulate in primary organs (i.e. heavy metals are not

69 biodegradable) and can therefore cause cancer (Khan and Malik 2014), one of the main reasons for

70 shorter life expectancy in many countries (WHO 2003). Beyond these health effects, effluents from

71 textile industries can directly affect the income of farmers by reducing production and indirectly

72 through higher medical expenses and reduced agricultural labor forces.

73 Effluents with concentrations above the legally permissible limits (e.g., table 1) are likely to degrade

74 and destroy local environments directly and indirectly by affecting the physical and biological 75 environment, such as land, water, and living organisms and human beings. For instance, high 76 concentrations Biological Oxygen Demand $\left(\mathrm{BOD}_{5}\right)$ increase the demands of Dissolved Oxygen (DO)

77 by decomposers, leading to the depletion of the Oxygen $\left(\mathrm{O}_{2}\right)$ required by other aquatic organisms to 78 survive. From the perspective of human health, some pollutants suppress the immune system, which 79 may have major - even deadly - health effects. This paper focuses on the negative impacts pollutants 80 have on the natural environment (as well as their effect on aquatic life and DO concentration) and its 81 implication on human health and livestock.

82 Ethiopia is an overwhelmingly agrarian economy. The agricultural sector absorbs around $85 \%$ of the 83 labor force and adds more than 40\% to the national GDP (MoFED 2014). While the industry sector 84 only contributed $10 \%$ to the GDP in 2008/09 and 12\% of the GDP in 2013, it's role remaining very 85 small. In 2011/12, the industry sector employed less than 5\% of the labor force (MoFED 2013; GTP 86 2013) and since 1990s, the Government of Ethiopia has taken a number of steps in an effort to 87 industrialize the economy and to promote industrial development. In general, the government has given 
specially emphasized manufacturing industries and textile industries in particular with the goal of utilizing natural resources and providing employment opportunities (IDS 2002; MoFED 2013). In the Ethiopian Constitution, Article 44 grants all citizens the right to live in a clean and healthy environment. Furthermore, Proclamation No. 300/2002, article 3 (1), stipulates that, "No person shall pollute or cause any other person to pollute the environment by violating the relevant environmental standard". Article 3 (2) of the same proclamation further states that the relevant authority or the relevant regional environmental agency may take administrative or legal measures against a person who, in violation of law, releases any pollutant into the environment. The towns of Dukem and Gelan in central Ethiopia were selected in 2004 in order to establish Industrial Development Centers (IDCs). So doing was part of the Ethiopian government's strategy to accelerate economic growth by establishing industrial development corridors in the selected town's

100 Regions (SNNPR), as well as in Addis Ababa and Dire Dawa since 2004. Thus, the selected IDCs, the federal government, or private companies in collaboration with the federal government, were enabled to establish Industrial Zones (IZs) that specialize in the manufacture of specific products in factories or 103 industries set up in a single premise (e.g., IZs for leather and leather products). The towns of Dukem and Gelan are located close to Addis Ababa, near the country's single railway line and major highway that connects Addis Ababa to Djibouti port. Both towns possess "sufficient converted agricultural land"

106 for investment, cheap labor, and sufficient underground water reserves. The area around Dukem and 107 Gelan have relatively low slopes - between 5\% and 10\% (OWWDSE 2011), making land preparation 108 and construction more cost effective than in other IZs in Ethiopia.

109 In order to attract investments from the domestic and international private sector, the Ethiopian 110 government offered investment incentives such as income tax exemption, customs duties for 111 machinery, capital goods, construction materials and vehicles, as well as access to bank credit and loss 112 carryforward in cases where it is needed (Regulation no. 270/2012). Attracted by these monetary and 113 non-monetary incentives, large numbers of investors (mostly domestic) were licensed shortly after the 114 establishment of IDCs in 2005. Our data obtained from the investment offices in Dukem and Gelan 115 shows that between 2005 and 2013 more than 460 projects of all investment types in Dukem and 300 116 projects in Gelan were approved. Of these, 257 projects in Dukem and 279 projects in Gelan belong to 117 the manufacturing sector: 23 textile and garment industries were licensed in Gelan town as were 118 between 12 and 20 in Dukem town. 
119 Generally, most of the licensed investment projects in the manufacturing sector were textile and 120 apparel, agro-processing, food and beverage, still and metal industries, and non-metallic construction 121 material industries. One of the pharmaceutical industries (Kadila Plc.) was also established in Gelan town. Field observations showed that, apparently, some of the operating factories have been 123 discharging effluents directly into the drainage channels and the nearby streams, which likely has an 124 impact on the quality of surface water, the environment and on the health of both humans and 125 livestock. In addition to this, it was evident that effluents have significantly eroded the aesthetic value 126 of the landscapes in these areas.

127 This study focuses on four textile industries (DH-GEDA, NOYA, ALMAHDI and ALSAR) established 128 between 2005 and 2008 in the peri-urban areas of Dukem and Gelan. Three of them are established and owned by foreign investors from China and Pakistan; one (DH-GEDA) is owned by an Ethiopian 130 company. With this as a backdrop, this case study focuses on the following objectives: understanding 131 the concentration levels of selected pollutants from textile industries and analyzing their effects on 132 biophysical environments. This study also tries to explore the level of exposure humans and livestock 133 have to polluted effluents and their effects.

\section{Methods and Materials}

137 The four case study textile industries, DH-GEDA, NOYA, ALMAHDI and ALSAR, are located in the 138 towns of Gelan and Dukem, part of Finfine Special Zone (FSZ), Oromia Regional State, 27 and 35 km 139 respectively south of Addis Ababa. NOYA and DH-GEDA are located between $8^{\circ} 48^{\prime} 0^{\prime \prime} \mathrm{N}-8^{\circ} 51^{\prime} 0^{\prime \prime} \mathrm{N}$ 140 latitude and 38 49'30"E - 38 52'30"E longitude in Gelan; and ALSAR and ALMAHDI are located in 141 Dukem town between $8^{\circ} 45^{\prime} 0^{\prime \prime} \mathrm{N}-8^{\circ} 48^{\prime} 0^{\prime \prime} \mathrm{N}$ latitude and 38 $52^{\prime} 30^{\prime \prime E}-38^{\circ} 55^{\prime} 30^{\prime \prime E}$ longitude (see Fig. 1). [insert Fig. 1]

144 Except for DH-GEDA, with close to 150 employees, the other three textile industries had a total of 145 between 450 and 500 employees by the end of 2013. As defined by the Central Statistical Agency of 146 Ethiopia (CSA, 2016), all four-textile plants are categorized as medium and large-scale industries from 147 this point (MLSI). All four factories primarily dye and bleach fibers (polyester and acrylic yarn) as a 148 raw material.

\subsection{Data sources}


The findings of this study are based on data empirically collected from two sources: laboratory analysis of sample effluents from the four selected textile plants and quantitative as well as qualitative socioeconomic data collection. During the 1950s, in the early days of modern water and wastewater quality monitoring, particular issues were rarely focused on. However, the water and wastewater quality assessment process has now evolved into a set of sophisticated monitoring activities that include the use of water chemistry, particulate material, and aquatic biota (e.g. Hirsch et al., 1988). Many manuals on water and wastewater quality monitoring methods already exist (e.g. Alabaster, 1977; UNESCO/WHO, 1978; Krenkel and Novotny, 1980; Sanders et al., 1983; Barcelona et al., 1985; WMO, 1988; WHO, 1992). Standard Methods for examining water and wastewater represent the best current practices of water analysis. This comprehensive reference covers all aspects of water and wastewater analysis techniques. In this study, the laboratory test methods and procedures applied in order to determine the parameters were based on the standard methods outlined and recommended by APHA (1999) and WHO/UNEP (1996). As part of the latter, a household survey and Focus Group

Discussions (FGDs) with elderly and other focal individuals were employed in Dukem and Gelan and the results from the different sources were triangulated. The procedures that were followed during the data collection are presented below.

\subsection{Physical sample collection for laboratory test}

\subsubsection{Preparation for field sample collection (Phase I)}

In Phase I, the sample sites were identified and all necessary preparations required for the sample collection were arranged in close consultation with the laboratory of the Environmental Protection Authority (EPA) in Addis Ababa. In the process of characterizing effluents from industries and on matters related to determining the quality of water, it was essential to work in close consultation with the EPA laboratory expertise in order to ensure the quality standards of the sample collection and the use of the analytical methods (see also APHA 1999). At the beginning of the fieldwork, we identified effluent discharge points for all industries and recorded their coordinates using Global Positioning System (GPS) devices. Furthermore, all required tools used to collect, preserve, and transport the samples were sorted, cleaned, and disinfected at the laboratory station. An icebox was prepared to transport the samples at a temperature of $4^{0} \mathrm{C}$ to the laboratory in Addis Ababa within less than eight hours after the sample collection. Codes, names and source of the samples were indicated on 
184 In Phase II (in June 2013), the actual samples were collected in the field, using grab and composite

185 methods. The grab method was utilized in order to take in-situ measurements of some parameters that otherwise would change their characteristics. A total of $200 \mathrm{ml}$ was taken from effluent discharge points and measurements for $\mathrm{pH}, \mathrm{EC}$, TDS and temperature were recorded using HANAN Instrument Model HI 98129.HI98130. In determining these parameters, appropriate calibrations and adjustments to all parameters were made at each stage before taking measurements. The Color and Turbidity level of the samples was determined with a Photometer 8000 (Palintest 8000 models). The next step was the collection of samples for laboratory tests. This was done using the composite method from which $250 \mathrm{ml}$ samples were collected five times at half an hour intervals. The samples were then mixed and put into one-liter airtight polyethylene cans (GEMS/WATER Operational Guide- $3^{\text {rd }}$ edition, 1992) that were stored in an icebox at a temperature of $4^{0} \mathrm{C}$ and transported to the EPA laboratory in Addis Ababa for physico-chemical and microbial analysis.

\subsubsection{Laboratory Analysis of the samples (Phase III)}

198 Phase III included entirely laboratory-based activities for the determination of physical and biological parameters for all the samples. The laboratory test methods and procedures were applied in order to determine the parameters based on the standard methods outlined and recommended by APHA (1999) and WHO/UNEP (1996). Moreover, the Standard Analytical Procedure for water analysis developed jointly by governments of India and the Netherlands in 1999 was applied. In the laboratory, the samples were pre-arranged and then sent for physico-chemical and microbiological analysis of Chemical Oxygen Demand (COD), Biological Oxygen Demand $\left(\mathrm{BOD}_{5}\right)$, Sulfide $\left(\mathrm{S}_{2}\right)$, Sulfate $\left(\mathrm{SO}_{4}{ }^{2}\right)$, Total Nitrogen (T-N), Nitrate $\left(\mathrm{NO}_{3}\right)$, Nitrite $\left(\mathrm{NO}_{2}\right)$, Total Ammonia (T-NH3), R-Phosphate (R-PO4)3, Magnesium (Mg) and Zinc (Zn) as well as for biological determination (Total Coli form and Fecal Coli form). In the microbiology lab, the Fecal Coli form (F. Coli) was determined by applying the membrane filter procedure with Laurel sulfate broth. The F. Coli counts were measured by filtering effluent samples with a special filter paper with a pore size of $0.45 \mu \mathrm{m}$ and $47 \mathrm{~mm}$ diameter. This filter paper allowd for the retention of all F. Coli bacteria on it, which was later placed on an absorbent pad ( $47 \mathrm{~mm}$ diameter) saturated with a F. Coli of medium growth and incubated at $44^{0} \mathrm{C}$ for 24 hours. After

212 incubation, the yellow colonies were counted, recording the number of counts per $100 \mathrm{ml}$.

\subsection{Qualitative, quantitative data collection and Focus Group Discussion}


215 Before initiating the household (HH) survey, Kothari's (2004) (Equation 1), simplified formula was 216 used to determine the optimum and representative sample sizes required for the survey. Of the total 217 seven kebeles in Gelan and Dukem, five kebeles (all the three of which were in Dukem with two out of 218 four in Gelan) ${ }^{1}$ were selected based on the presence of a large numbers of investments in the 219 manufacturing industry in general and of textile industries that discharge liquid effluents in particular.

220 A Kebeles is the smallest administrative unit of local government in Ethiopia, similar to a ward, a 221 neighborhood or a localized and delimited group of people. Each Kebele consists of at least five 222 hundred families, or the equivalent of 3,500 to 4,000 individuals. Out of $821 \mathrm{HHs}$ living in the five 223 selected kebeles, Gelan K, Tulu Guracha, Gogecha, Koticha and Xadacha, 262 HHs were distributed 224 proportionally to each kebele, which were interviewed using systematic random sampling (SRS) 225 methods. -Kanupriya (2013) suggests the use of SRS when the study population is small and 226 homogenous. In order to obtain complementary qualitative information, two Focus Group Discussions 227 (FGDs) were conducted with 12 elderly participants (6 each in Gelan and Dukem, Fig 2).

$228 \quad n=\frac{z^{2} \cdot \sigma_{p}^{2} \cdot N}{(N-1) e^{2}+z^{2} \cdot \sigma_{p}^{2}}$

Equation

229 Where:

$230 n=$ size of sample

$231 \quad N=$ size of population

$232 e=$ acceptable error (the precision)

$233 \sigma_{\mathrm{p}}=$ standard deviation of population

$234 z=$ standard variate at a given confidence level."

235 In this formula, the following assumptions were made: the size of population is 821 , standard error 236 (acceptable error) is 0.05 , standard deviation of population is 0.5 and values of standard variant at $95 \%$ 237 confidence interval ( $\mathrm{Z}$ ) is 1.96 . Thus, actual sample size was calculated as follows:

$238 n=\frac{(1.96)^{2} \cdot(0.5)^{2} \cdot 821}{(821-1)(0.05)^{2}+(1.96)^{2} \cdot(0.5)^{2}}=261.92 \sim 262$

239 Accordingly, 262 sample respondents were fixed for household surveys. [insert Fig. 2]

\footnotetext{
${ }^{1}$ Cafe Tumaa and Moreno kebeles without investment activities were not considered in this study.
} 
242 The FGD participants were selected based on the number of years lived in the kebele, and their role 243 within their respective kebeles. Additionally, expert interviews with textile factory managers and 244 technicians, veterinarians, and experts in the environmental protection units at levels of urban 245 administration in the study towns were conducted.

2 Results

\subsection{Physico-Chemical properties of the effluents}

249 Table 1 presents a list of the parameters for the physico-chemical and bacteriological characteristics of 250 textile effluents in Gelan and Dukem. Those parameters whose values exceed the permissible limits of 251 discharge into the inland surface water sources as outlined in the EPA guidelines are highlighted in 252 yellow. Accordingly, of the total 16 observed parameters in the samples from all investigated 253 industries, three parameters (COD, $\mathrm{BOD}_{5}$ and TSS) were found to be higher than the permissible 254 discharge limit. Conversely, a high level of $\mathrm{T}$. coli was recorded in effluents from ALSAR \& 255 ALMHADI while $\mathrm{S}_{2}$ was observed in effluents from DH-GEDA.

[Insert Table 1]

2.2 Comparisons of the concentration level of selected pollutants among the industries This section graphically presents the actual measured values of selected pollutants in all four observed textile industries. It aims to enhance the (visual) understanding of the concentration levels of pollutants against the limits ${ }^{2}$ allowed by the EPA guideline. Graphs also show the differences between our measured values (the straight black lines in the figures) and the tolerable concentrations for discharge into inland water sources, as permitted in the EPA guideline (the broken blue lines).

\section{i. $\quad$ Pollutants observed in high concentration in all selected industries}

266 The Biological Oxygen Demands $\left(\mathrm{BOD}_{5}\right)$, Chemical Oxygen Demands (COD) and Total Suspended 267 Solids (TSS) were found in high concentration in samples from all four of the selected industries (see 268 Table 1). Analyzing the concentration level of $\mathrm{BOD}_{5}$ is vital, as $\mathrm{BOD}_{5}$ is one of the most important indicators of water quality (WHO, 2008). Figure 3 shows that the concentration level of $\mathrm{BOD}_{5}$ in all of

\footnotetext{
${ }^{2}$ The maximum limit of discharge varies from one pollutant to the other one as it was stated in the EPA guideline (e.g., EPA Standard indicated in the last column of table 1).
} 
the samples taken from the four textile industries in Gelan and Dukem are above the permitted concentration limit of this pollutant into the inland water sources (broken horizontal line). [insert Fig. 3]

The highest concentration of $\mathrm{BOD}_{5}$ was observed in effluents from ALMHAD $(252 \mathrm{mg} / \mathrm{l})$, followed by DH-GEDA $(139 \mathrm{mg} / \mathrm{l})$. The values of $\mathrm{BOD}_{5}$ in effluents from NOYA $(91.50 \mathrm{mg} / \mathrm{l})$ and ALSAR $(84.00$ $\mathrm{mg} / \mathrm{l}$ ) were also higher than the concentration allowed by the EPA (Figure 3; Table 1: footnote 1). Another pollutant found in high concentrations was Chemical Oxygen Demand (COD). The COD content of the effluents from our case study strongly varies among the effluents from the sample industries. The lines in Figure 4 show that the lowest $(130.28 \mathrm{mg} / \mathrm{l})$ and the highest values $(733.5 \mathrm{mg} / \mathrm{l})$ were measured in DH-GEDA and NOYA respectively. In Dukem, the concentrations strongly vary between effluents from ALSAR (130.28mg/l) and ALMHADI (470mg/l). The COD level in effluents from NOYA and ALMHADI are nearly 5 and 3 times, respectively, higher than the concentration levels tolerated by the EPA. A study by Jekel (1997) shows an average pollution of $100 \mathrm{~kg} \mathrm{COD}$ is the result of one ton of finished products of fabric. Accordingly, the higher COD level in effluents from NOYA and ALMHADI may be due to more tons finished products. Also, the low quality of effluent treatment techniques used in NOYA and ALMHADI could also result in inefficient removal of pollutants below the level expected. Furthermore, the type and quality of chemicals used in the COD treatment plant would also affect the efficiency of pollutant removal (Magarde et al. 2009).

Another important parameter used to determine the pollution levels of effluents from the sample textile industries, is the concentration level of Total Suspended Solids (TSS). Textile industries uses organic and/or synthetic fibers as a raw material, which end up as part of the release of suspended solids in the wastewater.

Figure 5 also shows that another pollutant, TSS, was found in the samples with a high concentration level. The highest concentration was found in effluents from NOYA $(368 \mathrm{mg} / \mathrm{l})$, followed by ALMHADI (146mg/l), ALSAR (114mg/l), and DH-GEDA (46.5mg/l). The measured TSS values from NOYA, ALMHADI, and ALSAR are 12, 5, and 4 times, respectively, higher than the limit of $30 \mathrm{mg} / \mathrm{l}$ allowed by the EPA. One implication high TSS concentrations have on the environmental is that it 
blocks sunlight from pervading the water, which negatively affects photosynthetic plants and hampers

303 the oxygen production in the water (Prabu et al. 2008). Furthermore, in a study by Bukhari (2008), raw

304 municipal wastewater was electro-coagulated in order to remove TSS using stainless steel electrodes.

305 The result showed that the efficiency of TSS removal depends on the amount of iron generated from

306 the anode of the reactive electrode. Also, according to Meybeck et al. (2003), the temporal variability

307 of TSS decreases with an increased basin size, lake abundance, and is higher for basins influenced by

308 glacier melt and snowmelt.

309

310

ii. Pollutants limited to certain industries

312 industries, they were found in effluents from ALMHADI $(820 \mathrm{mg} / \mathrm{l})$ and ALSAR $(712 \mathrm{mg} / \mathrm{l})$ in higher

313 concentrations (Figure 6). Coli forms are the most common indicators of the microbiological 314 contamination of water used for domestic uses (WHO 2008).

315 The presence of all types of coli forms, especially of $E$. coli (also code-named $E$. coli 0157:H7), in 316 water used for domestic consumption can cause health problems for humans, children in particular 317 (WHO 2008). In spite of the potential health risk of water in streams or waterways, local people rely on 318 the water to meet their demands, especially for sanitation and livestock.

[insert Fig. 6]

\subsection{Effects of industrial effluents in the study areas}

\subsubsection{Aesthetic values and quality of local environment}

In spite of their importance for economic growth, industrial plants are generally associated with the generation and discharge of solid or liquid wastes. The reduce, reuse and proper recycling of these wastes require adequate financial and technological resources. In this regard, most industries in Gelan and Dukem have established neither treatment plants nor adequate storage or discharge channels for their wastes. As a result, polluted liquids are directly discharged into the open landscape (Fig. 7).

330 The volume of some discharged effluents was so high that they block local resident's walkways. Some 331 of them were discharged without even using decolorizes in order to remove the different dyes used 332 during the process of dying or bleaching the fibers and/or yarns (Fig. 7: a and b) or effluents with high 
333 turbidity levels (Fig. 7: c) that were discharged from NOYA, DH-GEDA and ALMHADI textile 334 industries respectively.

\subsubsection{Impact of Effluents on People's Health}

337 Another aspect of this study was to assess the effects of contaminated effluents from textile industries

338 on the health of people living around the textile factories, especially those living very close to the 339 factories and downstream along the discharge channels. According to data obtained from special 340 reports from the Oromia Regional State, close to $84 \%$ of the total population of Oromia Regional State 341 live in rural areas, with an average tap water supply of less than 50\% (ORS 2012). Accordingly, most 342 of the households living around the textile factories in Gelan and Dukem depend on surface water for 343 domestic use (Fig. 8).

Table 2 illustrates households' access to potable water for domestic use in the towns of Gelan and Dukem. It shows that most households have access to potable water for domestic use in both towns. Accordingly, nearly $84 \%$ and $82 \%$ of the households in Gelan and Dukem, respectively, replied that they have access to potable water. On the other hand, nearly $14 \%$ and $12 \%$ of the interviewed households in Gelan and Dukem, respectively, replied that they do not have access to potable water at all.

In this context, having access to potable water does not necessarily mean that these households are connected to a public water pipeline system in their compounds or at least close to their residences. Information obtained from the water and energy offices in Dukem and Gelan indicate that potable water supply coverage is less than $40 \%$ and that households obtain their water from different sources: public tap water, private houses and/or from the premises of some investors, and from open surface water sources such as streams and open channels. In some parts of Dukem and Gelan, investors have constructed ground water wells for industrial purposes, and at times, they allow residents who live close to the premise to tap these resources (Fig. 7). Yet, obtaining water from these sources is tedious

362 and access is restricted. Wells remain closed during daytime working hours, between 8.00 am to 5:30

$363 \mathrm{pm}$, and before and after residents have to wait in long queues to obtain a jerry cane of water every two 364 or three days. Households who live close to the urban centers travel longer distances in order to fetch 
365 water from public taps, for which they have to pay. Others buy water from private water traders.

366 Particularly poorer households and those who reside in areas that are rural, have to rely on surface 367 water from nearby rivers or streams - which is often contaminated by effluents from industries, textile 368 industries in particular.

369 The participants of the FGDs stated that residents who live along channels that transport textile 370 effluents and those who live downstream are more vulnerable than those who live faraway. Thus, in the

371 face of a very limited potable water supply and open surface discharge of industrial wastewater, the 372 likelihood of local people being exposed to effluents would by high. With this in mind, respondents 373 were asked if they think that any of their household members ever became sick because of the exposure 374 to industrial effluents locally discharged into open spaces, canals or streams.

375 The responses of the interviewees are shown in Table 3. They indicate that the perceived nexus 376 between health problems and the exposure to industrial effluents induced by textile industries was null 377 in Xadacha kebele, in Dukem ( $0.0 \%$ or 'Yes' answers), and relatively high in Gelan K (9.1\%), 378 T/Guracha (12,5\%), and Gogecha (14.7\%) kebeles in Gelan. In the Koticha kebele in Dukem, however, $37930.6 \%$ (19) of the interviewees said that at least one of their household members had become sick 380 following exposure to industrial effluents. Unlike all other kebeles, Koticha hosts both ALMHADI and 381 ALSAR textile industries. The incidence of health problems mostly related to skin allergies and 382 stomach health problems.

[Insert Table 3]

One of the participants in the FGD explained the health effects of polluted water in the following way: "At the very beginning no one realized that sickness such as skin disease (allergy) and other internal (stomach) health problems were related to the exposure to polluted water in the stream that we used to rely on for many years in the past. We were not given any orientation or warning against the potential health risks of polluted water. Those who walk bare foot and cross through the flow lines of effluents or polluted streams contracted skin allergy and internal disease. Besides, most of our children who look for the livestock in the open filed walk bare foot through polluted water; some of them who took bath in the polluted water contracted health problems, skin allergy in particular. As time goes on local people began distancing themselves from all the surface water except potable or pond water". 


\subsubsection{Health effects on livestock}

398 Livestock is a major source of income for many households in the study area and rearing livestock 399 depends on the availability of safe drinking water. Table 4 shows the principal sources of water for 400 livestock drinking are rivers and streams in Gelan $K(66.2 \%)$, Gogecha (58.8\%) and T/Guracha (50\%) 401 kebeles in Gelan. Conversely, households in Xadacha (83.3\%) and Koticha (72.6\%) use tap water to 402 water their livestock.

In spite of these differences, livestock is set free in order to graze in the open landscape during the long dry season and on the fields after harvest. Hence, the provision of tap water does not mean that livestock is not exposed to effluents (Fig. 9). This was also witnessed in the FGDs, where particular worries were expressed about the health of children who rely on milk and milk products from their own 409 livestock.

Based on the prevailing scenarios, an assessment was made in order to understand the magnitude of livestock health problems and the accompanied effects for which the result of the household survey data was displayed in Table 5.

Tabel 5 shows that the magnitute of assumed effects of effluents on the health of livestock vary in each 418 studied kebele, depending on its location and the level of access to the municipal water supply. The 419 livestock of residents who live in the downstream kebelesof Gelan $k$ and Koticha (Fig. 10) are 420 relatively more affected than those in upstream kebeles, like Xadacha and Gogecha. Most residents in 421 Gelan K, Koticha, and parts of T/Guracha kebele live downstream. Accordingly, 64.5\%, 56.3\% and $42250 \%$ in Gelan K, Koticha and T/Guracha kebeles, respectively, reported cases of sick livestock, 423 compared to $11.1 \%$ and $32.4 \%$ in Xadacha and Gogecha kebeles.

426 In order to assess the sources of water for livestocks and the health condition of livestock at the kebele

427 level, a Chi-Suare test was conducted and the results show that The Pearson Chi-Square test result 
shows that there is a link between the location of the study kebeles and the sickness of livestock: $\left(\chi^{2}=\right.$ 122.45, df $=6, P<0.05)($ Table 6).

[Insert Table 6]

In order to identify the types of livestock that are more vulnerable to health problems assumed to be cuased by polluted water, respondents were asked to reflect on their past experiences. Accordingly, of the five livestock categories considered in this study (cattle, donkey, horse, sheep, and goat), cattle were identified as most vulnerable, followed by donkeies, in all the study kebeles. Furthermore, in an expert interview, a veterinarian expressed his view on the nexus between livestock sicknesses and effluents as follows:

“Generally, microorganisms, pathogens are known for causing human or livestock health problems and that some of the effluents discharged from industries hold high amounts of organic loads: textile, food and beverage, tannery, etc. The presence of high organic loads amounts to the presence of microorganisms (aerobic/anaerobic) that survive by decomposing organic loads. Therefore, the use of water infected with pathogens means high risks of contracting disease by the livestock. Based on this fact, most of the livestock that were brought to the veterinary clinics for treatment were diagnosed for bacterial infections mainly "Salmonella". Based on our recorded data, more cases were reported for cattle and donkeys than other livestocks which were in fact much less in number among the livestock types owned by most households" (Question no. 8; expert interview conducted 20.02.2014).

The role of livestock on the livelihoods of households in the study area is immense. Therefore, their long lasting sickness or even death can easily disrupt the economic situation of a household.

\subsection{Economic costs of human and livestock treatments}

\subsubsection{Cost of medical treatment for a family member}

Another aspect of this study was to assess the economic costs of human and livestock treatments. This section shows the estimated costs that a household might pay for a medical treatment that is needed due to exposure to industrial effluents at a Kebele health post. The mean costs for a treatment for a sick individual were more or less similar in Gelan (US\$ 5.9) and Dukem (US\$ 4.0) in 2014 (Table 8). Based on the interviews made with drug dealers in Gelan and Dukem, the lowest costs arise when sick 
individuals purchase 'Paracetamol' (also called "pain-killer") in order to get relieve his/her pain or

461 from an itching skin due to a skin allegey. In extreme cases, however, a patient may pay total costs up 462 to US\$ 11.5 (and Dukem) and US\$ 15 (in Gelan) respectively (Table 7).

[Insert Table 7]

In this regard, an attempt was made to collect information on the economic costs of livestock treatment in a veterinary health post. Table 8 outlines the mean costs for treatment of cattle per visit.

[Insert Table 8]

The variations in livestock treatment costs between US\$ 1.8 in Gelan and US\$ 1.6 in Dukem, the slight variation in the treatment cost was mainly attributed to the level of sickness and the type of veterinary health posts visited. ${ }^{3}$ On the other hand, the loss of livestock due to health problems, which might be due to the exposure to polluted surface water, is a serious economic loss for the concerned households. Table 9 gives a summary of the average price of the livestock at local markets.

The mean market price of sick/affected cattle in Table 10 was calculated based on the estimated cattle price of the local markets. Respondents have estimated the price of their cattle at the local market between US\$50 and US\$ 600 (Table 10), based on age, size and health status of the animal. Therefore, losing cattle costs a household, on average, about 300 US\$ per animal.

\subsection{Community trainings and consultations}

483 According to proclamation no. 300/2002, the environmental awareness of local communities should be 484 raised through community training and/or consultations that would enable them to protect themselves, 485 as well as their property, against the danger posed by toxic substances. Against this backdrop, the question was raised to the interviewees if they ever received any form of training or consultation from

\footnotetext{
${ }^{3}$ Usually, private owned health posts are costlier than public ones. In Dukem town, most people bring their sick livestock to public health posts for which they pay less compared to Gelan where the prices are set by private clinic owners.
} 
members and/or their livestock against effluents from the nearby industries. The findings are shown in Table 10.

492 It is evident from Table 11 that the large majority of the respondents (79.4\%) did not receive any form

493 of information, training, and/or consultation at all. In the face of widespread and uncontrolled discharge 494 of effluents into the open environment (Fig. 2), this is an astonishingly high figure. Only $15.2 \%$ of the 495 interviewees reported that they received information on the potential harm caused by the industrial 496 effluents.

\section{Discussion}

499 The environmental and health related problems associated with wastewater discharged from textile 500 industries have since long been sources of global concern. Textile effluents consisting of high 501 concentrations of toxic chemicals and organic loads - often beyond the permissible limit - can alter the physico-chemical characteristics of humans, animals and plants, as well as whole ecosystems (Zaharia et al. 2011). Through this they produce multiple indirect economic costs, e.g. by reducing agricultural production, or by increasing the cost of drinkable water and health treatment. Of the total sixteen parameters observed in the laboratory, this study focused on and selected ones that help to determine the quality of water for different uses. The discussion involved comparing the values obtained in the laboratory and the permissible limit of discharge allowed focusing on why some of these pollutants were observed in large concentrations and the implications of polluted surface water on the health of humans and livestock.

\subsection{Major pollutants and their concentration levels against the national standards}

512 In all samples collected from the effluents of the four case study textile industries, six variables were

513 measured much higher than the permissible limit of discharge. Three of them $\left(\mathrm{BOD}_{5}, \mathrm{COD}\right.$ and TSS)

514 were observed in effluents from all four textile plants while the others were plant specific. In this 515 context, Islam et al. (2011) has found $\mathrm{BOD}_{5}, \mathrm{COD}$, TSS and $\mathrm{T}^{\circ}$ values of 573.89mg/l, 1223.33mg/l, $5161123.11 \mathrm{mg} / \mathrm{l}$ and $5022^{\circ} \mathrm{C}$, respectively, from samples taken from textile industry effluents in Gazipur 517 and Narayanganj cities in Bangladesh. Likewise, Singh et al. (2013) had conducted a study on effluents 518 from eight textile factories Punjab in India. Their results show concentrations of $\mathrm{BOD}_{5}$ between 
519 156mg/l and 790mg/l. Likewise, the measured values for COD and TSS concentration levels from the

520 same industries range from $120 \mathrm{mg} / 1$ to $3050 \mathrm{mg} / \mathrm{l}$ and $898 \mathrm{mg} / \mathrm{l}$ to $5145 \mathrm{mg} / \mathrm{l}$, respectively.

521 Likewise, the results of a study conducted by Siyanbola et al. (2011) on effluents from five textile 522 industries in Nigeria shows high concentrations of BOD 5 , COD, and TSS, between 340mg/l and $523560 \mathrm{mg} / 1$ for $\mathrm{BOD}_{5}$, between $615 \mathrm{mg} / \mathrm{l}$ and $1245 \mathrm{mg} / \mathrm{l}$ for COD, and between $0.11 \mathrm{mg} / \mathrm{l}$ and $310 \mathrm{mg} / \mathrm{l}$ for 524 COD. The measured values of temperature in wastewater discharged from textile plants in most cases 525 falls well within the national standards of their respective countries. In our study, however, an 526 exceptionally high temperature of $77^{\circ} \mathrm{C}$ was measured in effluents from the NOYA textile industry in 527 Gelan. This is nearly double the national and international permissible limit of the maximum 528 temperature of $40^{\circ} \mathrm{C}$ for discharged effluents, as well as the highest temperature measured in effluents 529 from textile industries worldwide. Islam et al. (2011) also measured an exceptionally high temperature 530 (i.e. slightly higher than $50^{\circ} \mathrm{C}$ ) in effluents discharged from a textile industry in Narayanganj city in 531 Bangladesh. A wastewater temperature of $77^{\circ} \mathrm{C}$ is likely to have strong negative impacts on the 532 surrounding animals, plants, soils, and wetlands. Another important pollutant identified in the sampled 533 effluents was T. Coli, where $820 \pm 195 \mathrm{mg} / \mathrm{l}$ and $712 \pm 37.0 \mathrm{mg} / \mathrm{l}$ were found in the samples taken from 534 ALMHADI and ALSAR industries, respectively.

535 The main reason for the presence of these pollutants in large quantities is attributed to the fact that most 536 textile industries use organic materials and fibers as raw materials. More importantly, the absence of 537 effluent treatment and/or the low quality of effluent treatment techniques used (e.g., due to age or 538 model) results in the pollutants being removed to a level below expected inefficiently. Furthermore, the 539 type and quality of chemicals used in the effluent treatment plant would also affect the pollutant's 540 removal efficiency (Magarde et al. 2009; Govindarajalu 2003; Khan and Malik 2013). It is important to 541 say that all industries investigated in this study, except NOYA, have their own effluent treatment plants 542 and yet still discharge highly polluted effluents. The measured values of the sampled effluent taken 543 from the NOYA industry showed that 8 of the 16 parameters are much higher than the national limits. 544 According to the technician who works on the effluent treatment plant and the manager of the company 545 (i.e. ALMAHDI), the design of the treatment plant and the chemicals they use were not effective. In an 546 expert interview, the ALMHADI manager indicated that they are aware of the problem, but that the 547 more effective wastewater treatment measures are expensive and priority of their company is profit.

548 Unlike ALSAR, ALMHADI was able to regulate the amount of most pollutants within the intended 549 national limit. For instance, of the 16 investigated pollutant types, the values of only 4 pollutants were 550 seen as slightly higher than the permissible limit. The values for all of the other 8 parameters were 
lower than the EPA regulation (Table 1). The manager of the company ALMHADI, was already aware

552 of the problem and was focused on an appropriate industrial waste management strategy.

\subsection{The environmental implication of wastewater from textile industries}

555

556

557

558

559

560

561

562

563

564

565

566

567

568

569

570

571

572

573

574

575

576

577

578

579

580

581

582

According to Kant (2012), effluents with high temperature and $\mathrm{pH}$ values above the tolerable limit (as proven in this study for the effluents from NOYA) could cause the extinction of important microorganisms. Likewise, the presence of high amounts of $\mathrm{BOD}_{5}$ in wastewater has led to the depletion of DO, which is important for the survival of wetland ecosystems. The environmental implication of high BOD5 in wastewater is associated with the removal of Dissolved Oxygen (DO), which is central for aquatic ecosystems. The amount of DO available in water is directly affected by the amount of BOD5 loads in effluents. High concentrations of BOD5 could create an ideal environment for the growth of microorganisms that survive by decomposing the organic matter using DO. Thus, at higher concentrations, BOD5 remove more DO that are equally required for the survival of other aquatic life, mainly fish and other aerobic organisms that will be threatened in such circumstances (Islam et al. 2011; Prabu et al. 2008; Kovaipunder 2003). The removal of more DO affects the availability of DO required for the plant's metabolism and reproduction (Mallya, 2007). COD was another pollutant found in large concentrations in the effluents sampled from all of our four case study industries. The main problem related to high COD concentrations is that it depletes available dissolved oxygen. In this environment, anaerobic microorganisms use DO to oxidize inorganic loads in the water. Hence, sustained removal of DO has a destructive effect on aquatic biodiversity by reducing the metabolism and the water's ability to recharge water oxygen.

In this study, we also considered $\mathrm{pH}, \mathrm{S}_{2}, \mathrm{NO}_{3}, \mathrm{P}_{-} \mathrm{SO}_{4}{ }^{3}$, and Zinc. The $\mathrm{pH}$ value is linked to the biological productivity of aquatic ecosystems in a way that does not deviate from the specified limit without risking damage to their productivity (Islam et al. 2011; Tüfekci et al. 2007). Given that, our study revealed that the $\mathrm{pH}$ value calculated for all industries was within the specified limit but that the measured value was very close to the margin of alkalinity (Table 1). According to WHO/UNEP (1999), $\mathrm{pH}$ values between 6.5 and 8.5 are within the typical range of most major drainage basins around the world and are usually referred to in order to indicate good water quality. According to our results, the concentration of Sulfate in effluents from DH-GEDA was slightly higher than the permitted discharge limit (table 1), indicating that its higher levels in the surface water would present health risks to people. Earlier studies have also demonstrated that high sulfate concentrations in water used by humans, could increases the chance of exposure to diarrhea (Khan et al. 2014). 


\subsection{Textile waste water and its effects on the health of the human and livestocks}

585 Households who reside far away from the towns of Dukem and Gelan and those who live downstream were found to be the most vulnerable to health problems. Generally, the relative number of human health problems associated with polluted surface water was much lower than the figures indicated for livestock.

According to the results of this study, children who live close to the wastewater discharge canals and those who live in downstream kebeles, were more affected than those who live farther away from wastewater sources and pathways. A verification of the principal causes of human health problems would, of course, demand medicinal diagnoses and specialized laboratory tests. Yet, the high levels of contamination in wastewater with different chemicals and the high T. Coli content as well as the high temperature of effluents, are considered as factors that contribute to human health problems. However, the magnitude of the problem varies within the study kebeles, especially with regard to the perceived nexus between health problems and industrial effluents (between 0,0\% in Xadacha and 30,6\% in Koticha). Residents in downstream areas and those who live in areas with limited or no access to potable water reported the highest occurrence of related health problems.

The main water-related problem for households is that the availability of public and private potable water sources was not sufficient to cover the demands of domestic households. Many households are thus forced to use water from open streams and drainage channels that are often polluted by effluents. Coli forms are the most commonly used indicators of contamination in drinking water. Water that contains coli forms should immediately be tested further for fecal coli forms or E. coli (see below).

604 Boiling coli contaminated water for one minute is a reliable way to disinfect it. Of the two types of the 605 pollutants, the presence of E. coli, also code-named E. coli 0157:H7, in the water used for domestic consumption, can cause human health problems, for children in particular (WHO 2008).

607 An important point observed in this study is the prevalence of livestock health problems to those 608 observed for humans. Yet, we observe considerable variations in the distribution of the problems: at 609 study town level, more livestock health problems were reported in Gelan than in Dukem (Table 5). At 610 kebele level, however, the results reveal that households in kebeles situated downstream were more 611 affected than those situated upstream. For instance, situated along the flow lines of the effluents where

612 livestock could easily access the wastewater, sickness among livestock was reported in Gelan $k$, and in 613 parts of T/Guracha and the Koticha kebele. This is primarily due to the absence of any alternative 614 sources of drinking water for the livestock and the people in the study kebeles. Thus, unless the issue 
615 of environment and the livelihood of these people are properly handled, the ongoing senario suggests

616 that there will be more damage to the environment and the livelihods of the local people.

\section{Conclusions}

619 Ethiopia is one of the least-developed countries worldwide and agriculture is the backbone of its 620 national economy. Conversely, the industrial sector is in its infancy, accounting for less than 5\% of the

621 work force and contributing less than 13\% to the national GDP. Since the formulation of the Industrial 622 Development Strategy (IDS), the Ethiopian government has taken a couple of proactive measures in 623 order to 'modernize' the economy by promoting the industrial sector. The main justification of the 624 industrial development project is its economic benefits at local, regional and national levels. However, 625 the project also showed some significant negative impacts.

626 Since 2005, Dukem and Gelan town have undergone rapid industrialization process that involved the 627 rapid flow of investors, whose origin is local. The results of this study revealed that the concentration 628 of some physico-chemical and bacteriological pollutants ( $\mathrm{BOD}_{5}, \mathrm{COD}$ and TSS) in textile effluents in 629 Gelan and Dukem is higher than the permissible limit defined by the Ethiopian Federal Environmental 630 Protection Authority (EPA). The concentrations of other pollutants, however, were below that limit.

631 This study also indicated that the environmental consequences of disposing untreated or inefficiently 632 treated wastewater into ambient environments damage the aquatic biodiversity. Moreover, one of the 633 critical problems of textile industries in developing countries is the management of the vast amounts of 634 waste generated. Challenges are particularly associated with disposal of wastewater into the ambient 635 environment. Therefore, in areas where development activities take place, consultation with the local 636 communities raise community awareness of development activities. Consultation or holding 637 community training boosts, not only the awareness and participation/support for development activities 638 in their locality, but also raises their awareness in protecting their family and properties from the 639 negative outcomes of the proposed or ongoing changes.

640 According to the findings of this study, the indiscriminate conversion of large tracts of prime 641 agricultural lands has been negatively affecting the livelihoods of the affected households in many 642 ways. In the first place, intensive land conversion caused a sharp reduction in the total cultivated land 643 size and the volumes of food crop production both at the study kebele and at household level leading to 644 household food insecurity. The study showed that industrialization and land use change has affected 645 household food security in three aspects. Firstly, they lost large agricultural land area (i.e. nearly half of 646 what they owned at the start of the program in 2005) for the establishment of industrial projects, which 
647 did not ensure stable jobs or better wage for peasants. Secondly, the expropriation of farmlands 648 significantly reduced the self-reliance of the households on food. Many of the surveyed households 649 reported that they are not able to produce enough food for their own consumption and high living costs 650 (i.e., due to reduced farmland size and production, none existence or limited opportunities of off-farm 651 and non-farm employment incomes) and the price of stable food crops is also increasing. Finally, 652 health problems (i.e. human and livestock) are found as an important result of deteriorating 653 environmental pollution in general and from the high risk posed by the industrial effluents.

654 Based on the findings of this study, many of the farming households are not comfortable with the 655 procedures involved in process of land expropriations. Because the lack of transparency during field 656 measurements of the expropriated farmland size, the elements considered in estimating the values of 657 their properties and in the final compensation amounts. The grievances of most of the affected 658 households are so intense in relation to the inadequacy of the compensation money and the manner in 659 which the compensation money was aid to them. Due to the very short notification period (sometimes 66030 days), the affected families are not given much time to adapt to changing living circumstances when 661 they lose their land.

662 Another grievance by the affected households was related to the low development level of the 663 converted lands and lack of off-farm or non-farm employment opportunities for some of the 664 households, where the income derived from agricultural activities is simply too low to cover all living 665 expenses either due to too small farmland size or turned into landless. Moreover, the younger 666 generations do not wish to work as farmers. Based on the results of the field GPS survey, although 667 agricultural land was converted into IZs, many licensed investors did not develop the land, hence did 668 not invest as initially proposed. This is confirmed by this study. It shows that the majority of the 669 licensed investors (72\% in Gelan and 63\% in Dukem) did not develop their land in a stipulated period.

670 In consequence, the substantial conversion of farmland into 'industrial land' negatively affects local 671 people not only through the loss of their farmland but through the lack of promised employment 672 opportunities and improved infrastructure that might have otherwise offset their losses in the 673 agricultural sector. In relation to employment opportunities, high labor migration coupled with labor 674 selection turned against the chances of getting opportunities for the local people where the level of 675 human capital development is very low and with no specific skill acquired by most of the unemployed 676 people except activities related to farming. As a result, those households who heavily rely upon 677 farming activities, on their own land or on the land of others by working as farm laborers, often have 678 more difficulties in taking care of their families when agricultural land conversion takes place and 
agricultural land holdings decline. In short, although non-agricultural activities are considered positively related to higher income and sustainable livelihoods, the success of non-agricultural trajectories depends upon the households' 'starting position'. It is no given that people, especially the poor, can actually take advantage of new employment opportunities outside the agricultural sector."

Finally, the results of this study can highlight a significant lack of comprehensive studies that can indicate the impact of textile industries effluents on the health of people in the towns of Dukem and Gelan. Accordingly, a study on the impact of textile industries' effluents on people's health in Dukem and Gelan should be considered in future studies.

\section{References:}

Alabaster, J.S. [Ed.] 1977 Biological Monitoring of Inland Fisheries. Applied Science Publishers Ltd., London, $226 \mathrm{pp}$.

APHA. (1999). Standard Methods for the Examination of Water and Wastewater. Environmental Protection Agency, $18^{\text {th }}$ ed., Washington DC, USA.

Azadi, H., Ho, P., \& Hasfiati, L. (2011). Agricultural land conversion drivers: A comparison between less developed, developing and developed countries. Land Degradation \& Development, 22, 596604.

Barcelona, M.J., Gibb, J.P., Helfrich, J.A. and Garske, E.E. 1985 Practical Guide for Groundwater Sampling. ISWS Contract Report 374, Illinois State Water Survey, Champaign, Illinois, 94 pp.

Bukhari, A.A. 2008. Investigation of the electro-coagulation treatment process for the removal of total suspended solids and turbidity from municipal wastewater. Bioresour Technol. 99(5), 914-21.

CSA (Central Statistical Agency of Ethiopia). 2016. International Standard Industrial Classification of All Economic Activities. http://www.csa.gov.et

EPA and UNEP. (2003). Standards for Industrial Pollution Control in Ethiopia, Addis Ababa, Ethiopia. FDRE (1992). Federal Democratic Republic of Ethiopia: Industrial Development Strategy, Ministry of Trade and Industry, Addis Ababa, Ethiopia.

Fisseha Itana. (1998). Metal concentrations of some vegetables irrigated with industrial liquid waste at Akaki, Ethiopia. Ethiopian Journal of Science, 96 (21), 133-144.

Govindarajalu, K. (2003). Industrial Effluent and Health Status: A Case Study of Noyyal River basin in: Martin J. Bunch, V. Madha Suresh and T. Vasantha Kumaran, (Eds.,) Proceedings of the Third International Conference on Environment and Health, Chennai, Indi a, 15-17. 
Gozálvez-Zafrilla, J., Sanz-Escribano, D., Lora-García, J., \& León Hidalgo, M. (2008). Nanofiltration of secondary effluent for wastewater reuse in the textile industry. Desalination, 222, 272-279

GTP. (2013). Growth and Transformation Plan; Ministry of Finance and Economic Development of the government of Ethiopia. Annual Progress Report for Fiscal Year 2011/12, Addis Ababa, Ethiopia

Hirsch, R.M., Alley, W.M. and Wilber, W.G. 1988 Concepts for a National Water-Quality Assessment Program. U.S. Geological Survey Circular 1021. United States Geological Survey, Denver, CO, 42 pp.

Islam, M., Mahmud, K., Faruk, O., and M. S., \& Billah, M. (2011). Textile Dyeing Industries in Bangladesh for Sustainable Development. International Journal of Environmental Science and Development, 2 (6), 428-436.

Jekel, M. (1997). Wastewater treatment in the textile industry. In: Treatment of wastewaters from textile processing. TU Berlin. Schriftenreihe Biologische Abwasserreinigung des Sfb 193, Berlin, pp. 15-24.

Kant, R. (2012). Textile dying industry and environmental hazard. Journal of Natural Science. 4 (1), 22-26.

Kanu, I., \& Achi O. (2011). Industrial effluents and their impact on water quality of receiving rivers in Nigeria. Journal Applied Technology Environment Sanit, 1(1), 75-86.

Kanupriya, C. (2013). Sampling Methods, (www.pitt.edu/ super7/43011-44001/43911.ppt), 09.06.2015.

Khan, S., \& Malik, A. (2014). Environmental Deterioration and Human Health. In: Malik, A; Grohmann, E.; Akhtar, R (Eds.) Environmental Deterioration and Human Health: Natural and anthropogenic determinants, 2014. V, 421 p.45. (http://www.springer.com/978-94-0077889-4)

Kothari, C.R. (2004). Research Methodology Methods and Techniques, Second revised edition, New Age International Plc Publishers, New Delhi, India.

Krenkel, P.A. and Novotny, V. 1980 Water Quality Management. Academic Press, New York.

Kumar, V. A. K., Chopra, A., \& Chauhan, R. (2012). Effects of Textile Effluents Disposal on water quality of Sub Canal of Upper Ganga Canal at Haridwar (Uttarakhand), India. Journal of Chemical and Pharmaceutical Research, 4 (9), 4206-4211. www.jocpr.com

Manunatha, N. (2008). Effect of Industrial effluents on Seed Quality attributes of Cereal Crops. Thesis submitted to the University of Agricultural Sciences, Dharwad University of agricultural sciences. Dharwad: India. 
Mark, S. (2004). Sustainability, Land use and Environment. A legal Analysis. Cavendish publishing ltd. London.

Mallya, Y.J. 2007. The effects of dissolved oxygen on fish growth in aquaculture. Kingolwira National Fish Farming Centre, Fisheries Division Ministry of Natural Resources and Tourism Tanzania.http://www.unuftp.is/static/fellows/document/yovita07prf.pdf

Merzouk, B., Madani, K., \& Sekki, A. (2010). Using eclectrocogulation-electrofication technology to treat synthetic solution and textile wastewater, two case studies. Desalination, 250, 573-577.

Meybeck, M., Laroche, L., Dürr, H. H., Syvitski, J. P. M. 2003. Global variability of daily total suspended solids and their fluxes in rivers. Global and Planetary Change, 39 (1-2), 65-93.

MoFED. (2013). Ministry of Finance and Economic Development of the Government of Ethiopia. Addis Ababa, Ethiopia.

Odjegba, V., \& Bamgbose, N. (2012). Toxicity assessment of treated effluents from a textile industry in Lagos, Nigeria. African J. of Environmental Science and Technology, 6 (11), 438-445.

Pamo, E.T. (2004). Water Development Strategy as a Driving Force for Sustained Rangeland Management by Local Communities in Sub-Saharan Africa. Environmental Monitoring and Assessment, 99 (1), 211-221.

Paul, S.A., Chavan, S.K., \& Khambe, S.D. (2012). Studies on characterization of textile industrial waste water in Solapur city, India. International Journal of Chemistry and Science, 10(2), 635642.

Prabu, P. C., Teklemariam, Z., Nigusse, T., Rajeshkumar, S.,Wondimu, L., Negassa, A., Debele, E., Aga, E., Andargie, A. \& Keneni, A. (2008). Characterization of Sewage wastewater and assessment of downstream pollution along the Hulluka River of Ambo, Ethiopia. Maejo International Journal of Science and Technology, 02 (2), 298-307.

Proclamation No. 300/2002. (2002). Environmental Pollution Control Proclamation; Federal Negarit Gazeta of the Federal Democratic Republic of Ethiopia, Addis Ababa, Ethiopia. Pp. 1959-1966.

Proclamation No.280/2002. (2002). Re-Enactment of the Investment Proclamation; NEGARIT GAZETA of the Federal Democratic Republic of Ethiopia, Addis Ababa, Ethiopia pp. 1768-1778.

Ranganathan, K., Jeyapaul, S., \& Sharma, D. (2007). Assessment of water pollution in different bleaching based paper manufacturing and textile dyeing industries in India. Environmental Monitor Assessment Journal,134, 363-372. 
Sanders, T.G., Ward, R.C., Loftis, J.C., Steele, T.D., Adrian, D.D. and Yevjevich, V. 1983 Design of Networks for Monitoring Water Quality. Water Resources Publications, Littleton, Colorado, 323 pp.

Shaikh, M. (2009). Environmental issues related with textile sector. Pakistan Textile Journal, 36-40.

Signh, D., Singh, V., \& Agnihotri, A. K. (2013). Study of textile Effluents in and around Ludhiana district in Punjab, India. International Journal of Environmental Sciences, 3 (4), 1271-1277.

Siyanbola, T. O., Ajanaku, K.O., James, O.O., Olugbuyiro, J.A.O., Adekoya, J.O. (2011). PhysicoChemical Characteristics of Industrial Effluents in Lagos State, Nigeria. Journal of Science and Technology, 1, 49-54.

Sponza, D.T. (2002). Necessity of Toxicity Assessment in Turkish Industrial Discharges (Examples from Metal and Textile Industry Effluents). Environmental Monitoring and Assessment, 73 (1), 41-66.

Tran, Q. (2013). Livelihood strategies for coping with land loss among households in Vietnam's suburban area. Canadian Center for Science and Education, 9 (15), 33-46.

Tüfekci, N., Sivri, N., \& Toroz, I. (2007). Pollutants of Textile Industry Wastewater and Assessment of its Discharge Limits by Water Quality Standards. Turkish Journal of Fisheries and Aquatic Sciences, 7, 97-103.

UNEP. (1992). GEMS/ Water Operational Guide, $3^{\text {rd }}$ Edition, GEMS/W 92.1.

UNIDO. (2012). Making it: Industry for Development, A Quarterly Magazine, Stimulating, critical and constructive forum for discussion and exchange about the intersection of industry.

USEPA. (1997). Handbook for Monitoring Industrial Wastewater, Nashville, Tennessee, USA.

UNESCO/WHO 1978 Water Quality Surveys. A Guide for the Collection and Interpretation of Water Quality Data. Studies and Reports in Hydrology 23, United Nations Educational, Scientific and Cultural Organization, Paris, 350 pp.

Verma, A., Dash, R., \& Bhunia, P. (2012). A review on chemical coagulation/flocculation technologies for removal of color from textile wastewaters. Journal of Environmental Management, 93,154-168 WHO. (2008). Water pollutants: biological agents, dissolved chemicals, non-dissolved chemicals, sediments, heat. WHO CEHA, Amman.

WHO 1992 GEMS/WATER Operational Guide. Third edition. World Health Organization, Geneva. WMO 1988 Manual on Water Quality Monitoring. WMO Operational Hydrology Report, No. 27, WMO Publication No. 680, World Meteorological Organization, Geneva, 197 pp. 
802 Pang, Y.L. \& Abdullah, A.Z. (2013). Current Status of Textile Industry Wastewater Management and 803 Research Progress in Malaysia: A Review. Clean: Soil, Air and Water, 41 (8), 751-764. $804 \quad$ http://dx.doi.org/10.1002/clen.201000318

805 Zaharia, C., Suteu, C., \& Muresan, A. (2011). Options and Solution of Textile effluent decolorization 806 using some specific physico-chemical treatment steps. Proceedings of the $6^{\text {th }}$ International 807 conference on Environmental Engineering and Management ICEEM'06, pp. 121 -122, Blaton $808 \quad$ Lake, Hungary.

809 


\section{Survey questionnaire for sampled informants}

813

\section{PART I}

\section{General Information}

\section{Location identification}

1. Woreda/town

2. Name of Kebele/village

3. Name of data collector

4. Date of data collection

PART II

I. Household demographic characteristics

1. Sex of household head:

a. male

b. female

2. Age:

3. Place of birth:

4. Marital status:

a. single

b. married

c. separated

d. widowed

e. divorced

5. Educational level:

e. $9-10$

f. $11-12$

g. $>12^{\text {th }}$

6. Ethnicity:
a. Oromo
b. Amhara
c. Tigre
d. other, specify,

7. Religion:

PART III: Questionnaire on the Livelihood Assets of a household

N.B. Multiple answers is possible where required

\section{Human capital/asset of a household}

839

1. If you are married or heads a family, please, indicate your family size by age, sex, educational status and major occupation:

\begin{tabular}{|c|c|c|c|c|c|c|}
\hline \multirow{2}{*}{ No } & Pseudo name & \multicolumn{3}{|c|}{ Remark } \\
\cline { 3 - 6 } & & sex & age & educational status & basic occupation (>1 answer is allowed) & \\
\hline 1 & & & & & & \\
\hline 2 & & & & & & \\
\hline 3 & & & & & & \\
\hline 4 & & & & & & \\
\hline 5 & & & & & & \\
\hline
\end{tabular}


1. Do you have agricultural land?
a. yes
b. no

2. Would you please mind indicating the size of each land use type for the years specified in the table?

\begin{tabular}{|l|l|l|l|l|}
\hline \multirow{2}{*}{ Land use type } & \multicolumn{2}{|c|}{ Size in local unit (i.e. qarxii) } & Remark \\
\cline { 2 - 5 } & Before 2004/05 & In 2008/09 & In 2012/13 & \\
\hline Cultivated land & & & & \\
\hline Fallowed land & & & & \\
\hline Grazing land & & & & \\
\hline Planted Forest land & & & & \\
\hline Others, & & & & \\
\hline
\end{tabular}

3. Would you please, tell total size of cultivated land and total amount of crops harvested over the years indicated?

\begin{tabular}{|c|c|c|c|c|c|c|}
\hline \multirow[b]{2}{*}{ Crop type } & \multicolumn{3}{|c|}{ Total size cultivated land (Qarxii) } & \multicolumn{3}{|c|}{ Amount produced (Qunt.) } \\
\hline & $2004 / 05$ & $2008 / 09$ & $2012 / 13$ & $2004 / 05$ & $2008 / 09$ & $2012 / 13$ \\
\hline wheat & & & & & & \\
\hline teff & & & & & & \\
\hline barley & & & & & & \\
\hline Oats & & & & & & \\
\hline maize & & & & & & \\
\hline peanut & & & & & & \\
\hline Horse bean & & & & & & \\
\hline Haricot bean & & & & & & \\
\hline Others, list & & & & & & \\
\hline
\end{tabular}

4. For how many months of the year that you annual crop production could able to feed your family?

b. 3-6 months

c. 6-9 months

d. 9-1 year

e. >1year

e. other, specify

5. What has happened to the size of your agricultural land over the past 8 years?
a. Increased
b. decreasing
c. intact
d. other, specify,

6. If your answer to Q5 is 'decreasing', what are the major causes for that? 

a. converted to investment in industries
c. Shared with family member

b. fall within urban housing expansion

d. other, specify,

7. If your answer to Q6 is ' $\mathbf{a}$ ', how many hectare/'qarxii' is converted to industrial establishment?
a. $0.25 \mathrm{ha}$
b. $0.25-0.5 \mathrm{ha}$
c.0.5- 0.75 ha
d.0.75-1ha
e. 1-1.5ha f. whole farm land g. other, specify-----

8. Were you consulted by local/regional government authorities about the conversion of your land?
a. Yes
b. No

9. If your answer to Q8 is 'yes', how did you decide/ were convinced to give up your land and properties on it?

a. voluntarily

b. order to cede

c. other, specify,

10. Were you paid compensation?

a. yes

b. no

11. If your answer to Q10 is 'yes' how much birr,

12. If your answer to Q10 is 'yes', how did you collect your compensation money?

a. all in one installment $\quad$ b. installment was made phase by phase

c. not yet paid

d. other, specify,

13. If your answer to Q10 is 'yes', how did you rate/compare the amount of compensation money with your land and properties on it if any? Compensation money was:

a. higher than aggregate value of my land and properties on it

b. was equivalent to the value of my land and properties on it

c. lower than the aggregate value of my land and properties on it

d. very much lower than the aggregate value of my land and properties on it

e. Other, specify

14. What did you do with the compensation money? Explain, four major activities

a.

b.

c.

15. How do you rate your household's current living status and standards before collecting compensation money and after collecting compensation? Do you thing, your living status and standard improved significantly

c. unsure

16. Have you ever displaced from your residential areas to cede your land for ongoing investment activities in your $\begin{array}{lll}\text { area? } & \text { a. yes } & \text { b. no }\end{array}$

b.

c. 
1. Do you have access to supply raw materials from your produce (crops, livestock, etc) for operating industries in your area?

a. yes

b. no

2. If your answer to Q1 is 'yes', would you please, specify top three items in order of their importance for you,

a.

b.

c.

3. Do you have an opportunity/possibility to purchase consumable products produced from operating industries in your area?

a. yes

n. no

4. If 'yes' to Q3, what type of consumable goods? Please list top three important items and compare prices with conventional market price

a.

b.

c. (cheap, similar, expensive)

(cheap, similar, expensive)

(cheap, similar, expensive)

\section{Employment opportunities in relation industrial activities}

1. Can you indicate employment history of your household members?

\begin{tabular}{|c|l|l|l|l|l|l|}
\hline Employment Status & male & age & female & age & total & Remarks \\
\hline employed & & & & & & \\
\hline unemployed & & & & & & \\
\hline
\end{tabular}

3. If your answer is 'yes', can you indicate the type of employment? ( $>=$ one answer possible)
a. Daily laborer
d. professional work, specify

921

b. Foreman

e. other, specify

c. compound keeper

4. How much is the average monthly income for unskilled household member employed in industry? (in birr)
a. $<500$
b. $501-750$
c. $751-1,000$
d. $1,001-1250$
e.1251-1500
f. $>1,500$

5. What is the household monthly saving from the income obtained from employment in the industry?

a. $<100$ birr

b. $101-150$

c. $151-200$

d. $201-250$

e. $251-300$

f. other, specify ------

6. Do you and/or other people in your locality have access to employment opportunities in the processes of industrial establishment?

a. yes

b. no

7. If your answer to Q6 is 'yes', what type/s of employment/job opportunities are easily/ commonly available for local people in your area? Indicate in terms of their decreasing order of availability

a. Wage labor

b. daily labor

c. compound keeper

c. casual work

d. other, specify-----

8. What are the major problems related to employment in industries? 

a. lack of education
b. lack of skill
c. availability of excess labor from other places

d. employers are selective: prefer people from urban origin than from rural area

e. other, specify

9. What implication (positive-negative) do you think employment in the industries has on own agricultural activities in your locality? Please, put in order of their importance

e. other, specify

10. Do you agree with the processes of rapid industrialization and the accompanied rural land conversion in your area?
a. Strongly agree
b. agree
c. unsure
d. disagree
e. strongly disagree

11. If rapid industrialization is associated with major negative impacts, what do you suggest to be undertaken by the government to avoid or reduce the negative impacts in your locality?

a.

b.

1. When did you get access to the following infrastructures in your locality/Keble? Please, put thick mark ' $\sqrt{ }$ ' based on the years indicated in the table,

\begin{tabular}{|l|l|l|l|l|}
\hline Type of Infrastructure & $2004 / 05$ & $2008 / 09$ & $2012 / 13$ & Remark \\
\hline paved & & & & \\
\hline Gravel & & & & \\
\hline Coble stone & & & & \\
\hline Asphalt & & & & \\
\hline Potable water & & & & \\
\hline Power/electric & & & & \\
\hline Health centers & & & & \\
\hline School & & & & \\
\hline i. $1-4$ & & & & \\
\hline ii. 5-8 & & & & \\
\hline iii. 9-10 & & & & \\
\hline
\end{tabular}

\section{Financial capital/assets}

\section{A. Income and saving}

1. Do you have your own savings of money in liquid and/or grain form to be used for emergencies and/or other household use purposes?

c.

I do not have any idea about saving

2. Did you or any of your family members involve in non-agricultural income generating activities? 

a. Yes
b. No

3. What do you or your family member do with the income obtained from non-agricultural activities?

a. purchase food

c. pay back debts

d. purchase farm implements and inputs

e. other, specify,

963

\section{B. Livestock ownership}

965

1. Do you own livestock?
a. Yes
b. No

2. If your answer to Q2 is 'yes', please give us the following details for the periods indicated in the following table

\begin{tabular}{|l|l|l|l|}
\hline Livestock category & \multicolumn{3}{|c|}{ Year } \\
\hline cattle & $2004 / 05$ & $2008 / 09$ & $2012 / 13$ \\
\hline oxen & & & \\
\hline caw & & & \\
\hline calves & & & \\
\hline heifers & & & \\
\hline bulls & & & \\
\hline Sub-total & & & \\
\hline Equines & & & \\
\hline horse & & & \\
\hline donkey & & & \\
\hline mules & & & \\
\hline Sub-total & & & \\
\hline Ruminants & & & \\
\hline sheep & & & \\
\hline goat & & & \\
\hline Sub-total & & & \\
\hline others & & & \\
\hline chickens & & & \\
\hline
\end{tabular}

3. Do you face animal feed problems such as communal and/or own grazing land shortages over the last five years back from 2011 ?
a. Yes
b. No

4. If your response to Q3 is 'yes', what is/are the causes?

a. shrinking of own grazing land

b. lack of communal grazing lands

c. communal grazing land converted to investment and settlement activities

5. If your answer to Q3 is 'yes', what measures did you take to overcome shortages of grazing lands/pasture? 
A. Schooling

1. Are there any children in your family who are not going to school over the last five years?

a. yes

b. no

2. If your answer is yes for Q1, what are the major reasons for not sending children to school? (> 1 answer is possible)

a. Unable to afford school expense

b. In need of child labor

987

d. Absence of schools

e. Schools are far from home
a. Yes
b. No

\section{B. Socio-cultural aspects}

f. Lack of awareness

g. Abduction of girls

h. Changing place of living

i. Other, specify

3. Are there any children in your family who dropped out of school over the last five years?

4. What are the major reasons for school dropout? (More than one answer is possible)

a. Economic problems (Unable to afford school expense)

b. In need of child labor

c. Absence of schools

d. Schools are far from home e. Lack of awareness

f. Abduction of girls

g. Changing place of living

h. Other (specify)

1. What main socio-cultural problems/prospects is/are emerging and how do you rate their trends after industrial establishments in your locality? Please, write the later of your choice in front of each question

\begin{tabular}{|l|l|l|}
\hline Types of social problems/opportunities & a. severe b. moderate & $\begin{array}{c}\text { a.increasing b. decreasing } \\
\text { c. constant d. not sure }\end{array}$ \\
\hline Theft & b. low d. no problem observed yet & \\
\hline Conflict over grazing land & & \\
\hline Conflict over agricultural land & & \\
\hline Juvenile delinquency & & \\
\hline Commercial sex workers & & \\
\hline Beggary & & \\
\hline Unemployment & & \\
\hline Street-ism and orphan/child related problems & & \\
\hline Disability - related to working in industries & & \\
\hline Elders without support & & \\
\hline Alcoholisms & & \\
\hline Jigii & & \\
\hline Idirii & & \\
\hline Equbii & & \\
\hline Other, list and rate & & \\
\hline
\end{tabular}


Part IV.

\section{Environmental Assessment}

1. What are your current sources of water for household consumption in your locality?

2. If you answer to Q2 is ' $\mathbf{a}$ ', what do you do with it?
a. Drinking
b. for cooking
c. bath

d. washing and sanitation

e. other, specify

3. How do you rate the quality of river/stream water in your area for human uses after the processes of industrial establishment based on your local knowledge/experience?

4. If your answer to Q3 is 'd', did you or your family member get sick of using river/stream water for drinking?

$$
\begin{array}{ll}
\text { a. Yes } & \text { b. No }
\end{array}
$$

5. If your answer to Q4 is 'yes', how many of family member got sick on average in a year? -----indicate age

6. Did you or any of your family members visit health center for medical treatment so far up when sick?
a. Yes
No.

7. If your answer to Q6 is 'yes', how much money did you pay on average each time you or your family visited health centers?

8. Did any of your family member/ relatives die of sickness due to drinking river/stream water so far? Please indicate their age -------------- a. Yes b. No

9. What are the most common diseases prevailing in your area over the last five years? (More than one answer is possible)

\section{h. Eye disease}

i. Tonsillitis

j. Other (specify)

10. What other impact/s does using river water in your area bring on your family, livestock and agricultural activities?

c. Other specify

11. What is/are the principal sources of water for livestock consumption in your area?

a. River/stream water

b. pond

c. potable water

d. other, specify

12. Did you or your livestock get sick of using polluted river water for drinking?
a. Yes
b. No

13. If your answer to Q12 is 'yes', how many of your livestock got sick on average? -indicate age-

a. yes

b. no

15. If your answer to Q14 is 'yes', how much money did you pay on average each time for treatment?

16. Which livestock types are more vulnerable to health problems up on using river/stream water in your area?
a. Cattles: ox, caws, calves heifers, bulls
b. equines
c. small animals (sheep, goats)
d. other specify ------

17. Would you please, mention three pressing health problems of your livestock after industrialization process begins in your locality in terms of their order? 
a.

b.

18. What other impact/s does using river water in your area bring on people, livestock and agricultural activities?

a. Farm labor often affected

b. Affected agricultural production

c. Livestock incomes such as milk and milk products declined

d. Abortion and maternal health problems

e. Deaths among calves

f. Other, specify

19. What do you think should be done by you, local administration, investors and government at higher levels do in order to reduce or avoid the principal sources of river/stream water pollution in your locality and enhance the usability of the river/streams?

b.

1054

c.

1055

1056

Part V

1057

1058

Which of the following best represent your Copping and adaptations Strategies to farmland losses?

1059 (Multiple responses are possible)

1060

1061

1062

1063

1064

1065

1066

1067

1068

1069

1. How do you cope with problems of land and food shortages for your household? Please, put ' $\sqrt{ }$ ' mark (>1 answer possible)
a. share cropping
j. consume less preferred food
b. land rent
k. borrowing grain from relatives/neighbors
c. work in others farm
1. cash/money loans from merchants
d. diet change: type, quantity and quality reduction
m. labor sale: work for the others farmers
e. livestock sale
n. grass sale
f. ox/oxen, equines rent
o. fuel wood and animal dung sale
g. farm land renting
p. daily labor in investment sites
h. buy food on credit basis
q. sale of hand crafts
i. migrate to urban centers
r. other, list

1070 